\title{
Synthesis of Ruthenium Bipyridyl Linked with Steroidal Oxidative Quencher for Photo Redox Studies
}

Gondi Sudershan Reddy ${ }^{1^{*}}$

\begin{abstract}
Affiliations:
${ }^{1}$ Department of Chemistry, National Taiwan Normal University, Taipei, Taiwan, 116 (ROC).

a Correspondence to: gondisr@gmail.com
\end{abstract}

Abstract: Synthesis of ruthenium bipyridyl linked with steroid having oxidative quencher, viologens for study of photo redox properties were described.

Key words: Photoredox, Ruthenium bipyridyl, Steroids, Viologens, Oxidative Quencher

Introduction: Over the past decade, photoredox catalysis has risen to the forefront of synthetic organic chemistry as an indispensable tool for selective small-molecule activation and photoinduced chemical reactions ${ }^{1-4}$. This cutting-edge platform allows photosensitizers to convert visible light $^{5}$ into chemical energy 5,6 , prompting generation of reactive radical intermediates ${ }^{7}$. The photochemical and thermal chelate exchange reactions involving $\mathrm{Ru}(\mathrm{bpy}) 3$ ${ }^{2+}$, where bpy is 2,2-bipyridine, and derivatives have been reported ${ }^{8}$. The extent of these photo reactions depends on these ligands under light conditions. A recent report ${ }^{9}$ on the high yield synthesis of 4 -carboxylic acid-2,2 $2^{1}$-bipyridine-4 $4^{1}$-methyl (MebpyCOOH) has paved a new avenue in the research of ruthenium polypyridyl complexes to biomolecules ${ }^{10,11}$. Only one acid group significantly simplifies the connection of this type of ruthenium complex to biological molecules with amine groups ${ }^{12-14}$. 
It is most attractive feature if ruthenium connected to through a non-conjugate bridge biomolecules having oxidative quencher, such as Viologens ${ }^{15}$. because ruthenium and oxidative quencher viologens have their spectroscopic versatility. Both the donor $\left(\operatorname{Ru}(\mathrm{bpy}) 32{ }^{*}\right)$ and acceptor groups can be probed by a variety of different spectroscopic methods. Cholic acid $^{16}$ is one of the primary steroids, it has three hydroxyls groups oriented at positions of $\mathrm{C} 3 \alpha$, $\mathrm{C} 7 \alpha$ and $\mathrm{C} 12 \alpha$ on the polar concave side of the molecule, which is defined as hydrophilic $\alpha$ face. Its hydrophobic steroidal backbone is defined as $\beta$-face. The facial amphiphiles of cholic acid can lead to self-aggregation in solution or aggregation with other specific supramolecular arrangement. Therefore, cholic acid has been widely used as the building block in supramolecular chemistry to transport ions and polar molecules through various membranes. In addition, cholic acid can be potentially used as an adjuvant of liver-specific drugs and absorption enhancers. Similarly, viologens are a well-studied species exhibiting three reversible redox states, possessing valuable electrochromic and electron-accepting properties. because of its properties, viologens have become of great interest as functional materials in a wide array of applications; a few to name include electrochromic devices, molecular machines, and organic batteries ${ }^{17}$. In the combined molecules, if reduction of the biomolecule is desired, a directly photoinduced electron transfer from ruthenium polypyridyl complexes through the bridging ligand, Mebpy- $\mathrm{COOH}$, can be performed. ${ }^{18}$ If oxidation of the biomolecule is desired, a flashquench method can be employed ${ }^{19,20}$. In the flash-quench method, the excited ruthenium polypyridyl complexes have to be quenched from the non-bridged ligands first, followed by the ET through a bridging ligand ${ }^{21}$. 
Present work: In our lab, after synthesizing the Fluorescence Probe ${ }^{22}$ to investigate cytochrome $c$ folding kinetics, herein we disclosed the synthesis of a complex molecules having photoredox ruthenium bipyridyl were linked with biomolecules having oxidative quencher, viologen. Herein we used lithocholic acid instead of cholic acid to simplify the synthetic route.

Synthesis Part: Commercially available lithocholic acid was esterified in presence of PTSA to obtained ester 1, in $90 \%$ yield, which on reduction by using LAH to get the diol, 2 in $85 \%$ yield. Selective mono tosylation by using tosyl chloride in presence of base, TEA for $72 \mathrm{~h}$ at $4^{\circ} \mathrm{C}$, isolated the mono-tosylated product 3 , which successfully converted to iodo product ${ }^{23} 4$ in $70 \%$ yield, under reflux condition with sodium lodide in acetone. The mono viologen ${ }^{24} \mathbf{5}$, is obtained 88 yield by following the modified procedure. Treating the mono viologen $\mathbf{5}$ with iodo compound 4 in presence of DCC reagent ${ }^{25}$ to obtain the salt, which was characterized by NMR and Mass. (Scheme-1).

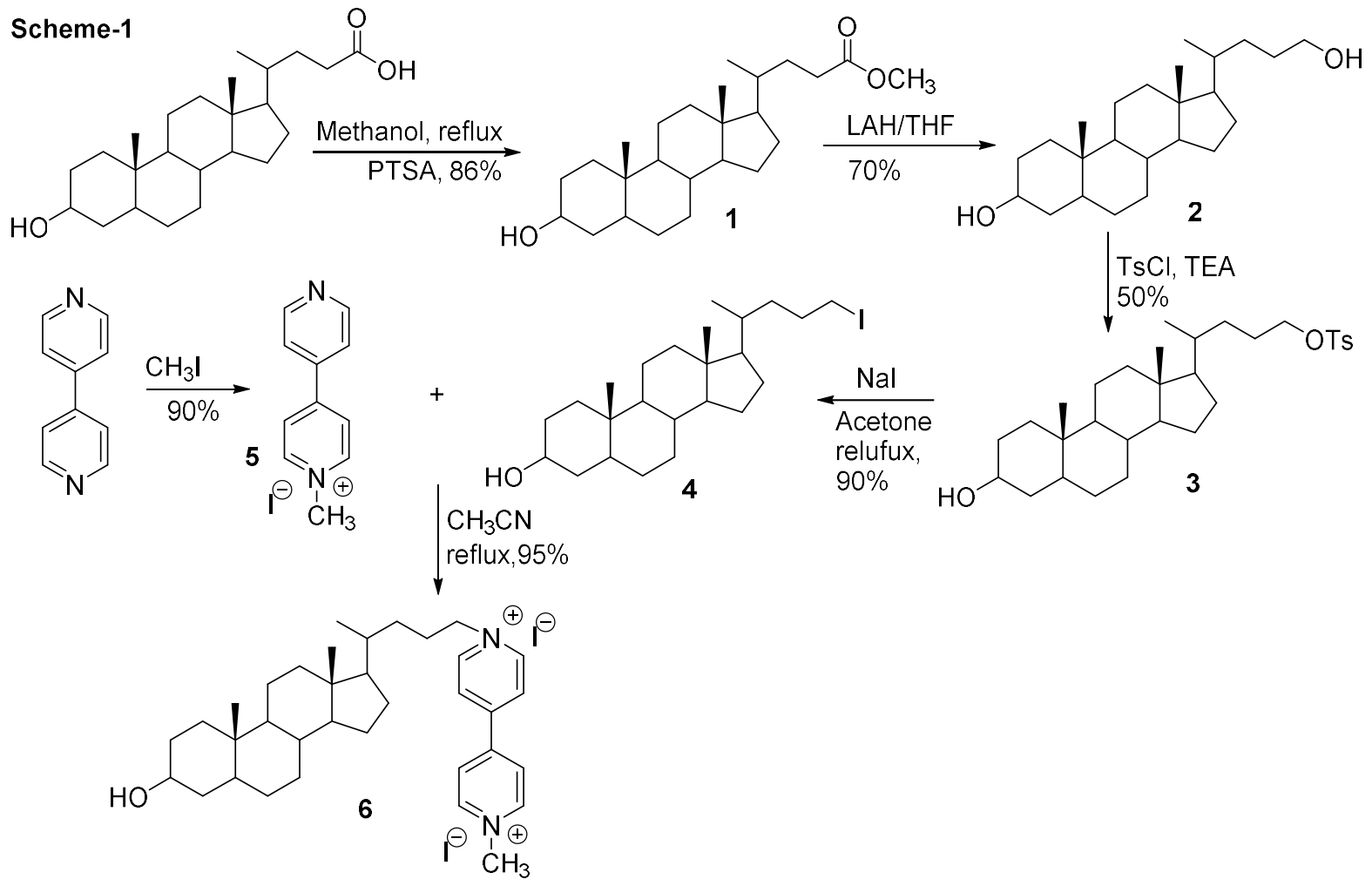


4-Picoline was treated with palladium under reflux conditions obtained the bipyridy ${ }^{26} 7$, in $20 \%$ yield.

Selectively oxidation of 7 to mono-aldehyde $\mathbf{8}$ by using selenium dioxide ${ }^{12}$, which on further oxidized using freshly prepared silver oxide ${ }^{27}$ to obtained acid 9 in 55\% yield. (scheme-2)

\section{Scheme-2}

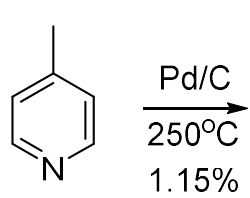<smiles>Cc1ccnc(-c2cc(C)ccn2)c1</smiles><smiles>Cc1ccnc(-c2cc(C=O)ccn2)c1</smiles><smiles>Cc1ccnc(-c2cc(C(=O)O)ccn2)c1</smiles>

The bipyridyl acid $\mathbf{9}$ coupled with steroid linked with steroidal-viologen $\mathbf{6}$, to obtained product ${ }^{10,28,29} \mathbf{1 0}$ in 95 yield. (scheme-3).

Scheme-3<smiles>Cc1ccnc(-c2cncc(C(=O)O)c2)c1</smiles><smiles></smiles><smiles></smiles>

Ruthenium carbonate is prepared in two steps by treating 2,2-bipyridyl with ruthenium trichloride to obtained intermediate product ${ }^{30}$ in $40 \%$ yield, which on treated with sodium carbonate under Argon atmosphere gives ruthenium carbonate ${ }^{8}$ in $67 \%$ yield. (scheme-4)

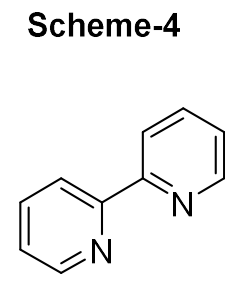

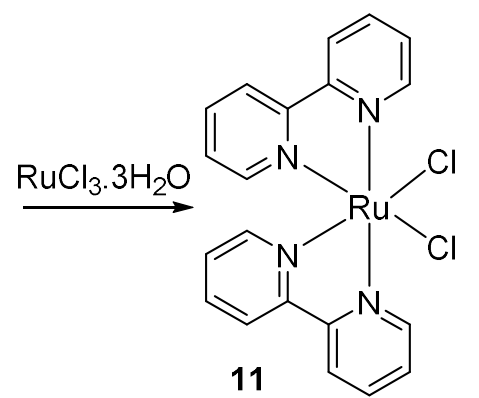<smiles></smiles>

Ruthenium carbonate on treated with compounds 10 under heating condition. The product was separated by using the solubility differences of substrates to get $120 \mathrm{mg}$ of pure product ${ }^{31,32}$ in $59 \%$ yield. (scheme-5). 


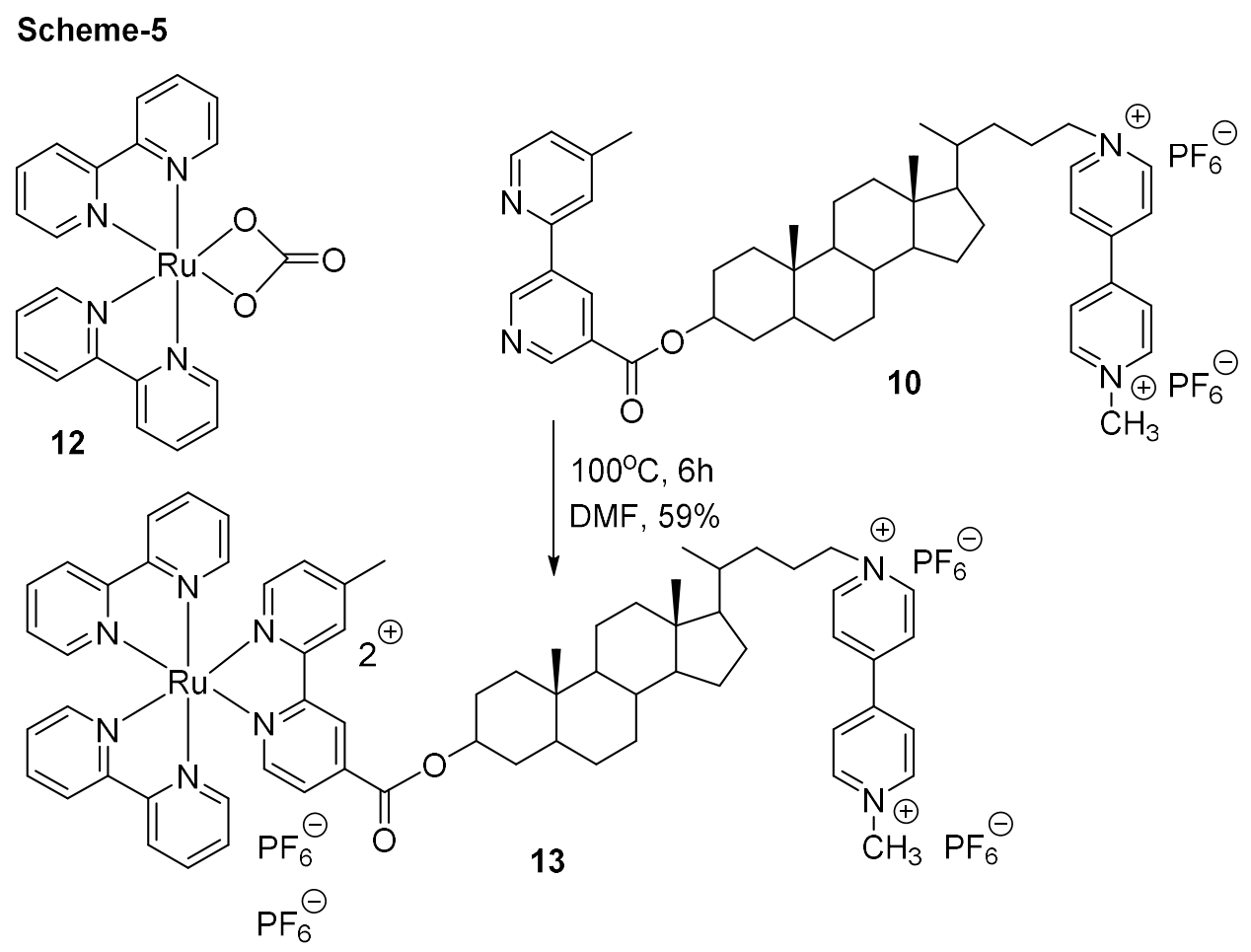

Conclusion: A photoredox complex molecule with lithocholic acid groups as Lineker between Ruthenium bipyridyl and mono viologen was successfully synthesized by coupling reactions for the first time to study its photo redox, fluorescence, and electrochemical properties.

Experimental Part: All reagents were purchased from commercial sources and used without any further purification. Technical solvents were used unless otherwise stated. Anhydrous solvents were obtained by passing solvent through columns of molecular sieves in a solvent purification system. Flash chromatography employed 230-400 mesh silica gel. Solvents used for chromatography are quoted as volume/volume ratios. Analytical thin layer chromatography was performed using silica gel plates precoated with silica gel 60 F254 $(0.2 \mathrm{~mm})$ using UV light and $10 \%$ ethanolic solution phosphomolybdic acid dip to visualize the products. ${ }^{1} \mathrm{H}$ NMR spectra were recorded at $298 \mathrm{~K}$ unless otherwise stated using Varian VXR (200 MHz) spectrometers. Data is expressed in parts per million (ppm) downfield shift from tetramethyl 
silane with residual solvent as an internal reference $\left({ }^{\delta} 7.26 \mathrm{ppm}\right.$ for chloroform) and is reported as position ( $\delta$ in ppm), multiplicity $(s=$ singlet, $d=$ doublet, $\mathrm{t}=$ triplet, $\mathrm{q}=$ quartet $=$ multiplet), coupling constant $\left(J\right.$ in $\mathrm{Hz}$ ) and integration (number of protons). ${ }^{13} \mathrm{C}$ NMR spectra were recorded at $298 \mathrm{~K}$ unless otherwise stated using Bruker Avance III $100 \mathrm{MHz}$ spectrometers with complete proton decoupling. Data is expressed in parts per million (ppm) downfield shifts relative to the internal reference ( $\delta 77.2 \mathrm{ppm}$ for the central peak of deuterated chloroform) and is reported as position ( $\delta$ in ppm). IR spectra were recorded on a Perkin Elmer 688 spectrometer. Mass spectra were obtained on a Shimadzu QP 1000 spectrometer. High resolution mass spectra (HRMS) were recorded using electrospray ionization on a Time of Flight (TOF) mass spectrometer at National Taiwan University.

Lithocholic acid methyl ester (1): Dissolved the lithocholic acid (5.0 g, $13.2 \mathrm{mmol})$ in methanol (150 mL) and added PTSA (455 mg, $2.65 \mathrm{mmol}$ ) and stir at RT for $24 \mathrm{~h}$. Removed the solvent on rota evaporator, extracted with ethyl acetate $(100 \mathrm{~mL} \times 2)$ and washed with $10 \%$ $\mathrm{NaHCO}_{3}$ solution, brine solution, dried over $\mathrm{MgSO}_{4}$ and filter. Concentrated under reduced pressure on rota evaporator to give a residue which was purified by column chromatography by using $30 \%$ ethyl acetate in hexane, to obtained $4.5 \mathrm{~g}$ of the product in $86 \%$ yield. Melting point is $128-130^{\circ} \mathrm{C} .{ }^{1} \mathrm{H}$ NMR $\left(200 \mathrm{MHz}, \mathrm{CDCl}_{3}\right)$ : $\delta 3.65(\mathrm{~s}, 3 \mathrm{H}), 2.41-2.10(\mathrm{~m}, 2 \mathrm{H}), 2.00-0.81(\mathrm{~m}$, 20H), 0.63 (s, 3H) $\left.{ }^{13} \mathrm{C} \mathrm{NMR} \mathrm{(50} \mathrm{MHz,} \mathrm{CDCl}_{3}\right): \quad \delta 174.8,71.6,56.3,55.8,51.3,42.5,41.9,40.2$, $40.0,36.2,35.6,35.2,34.4,30.8,30.8,30.3,28.0,27.0,26.2,24.0,23.2,20.6,18.0,11.8$. IR $(\mathrm{KBr}): 1748,1540,1320,925,750$. Mass: $(\mathrm{m} / \mathrm{z}): 390(\mathrm{M}+)$. 
$5 \beta$-Cholane-3 $\alpha$-24-Diol (2) Dissolved the lithocholic acid methyl ester $(5.0 \mathrm{~g}, 12.8 \mathrm{mmol})$ in 50 $\mathrm{mL}$ of THF and cool to $0^{\circ} \mathrm{C}$. Added Lithium aluminum hydride $(970 \mathrm{mg}, 25.6 \mathrm{mmol})$ portion-wise over a period of 10 minutes. Heated at reflux for $4 \mathrm{~h}$. Cool to room temperature and remove the solvent on rota evaporator. Extracted with ethyl acetate $(100 \mathrm{~mL} X 2)$ and washed with $10 \%$ $\mathrm{NaHCO}_{3}$ solution, brine solution, dried over $\mathrm{MgSO}_{4}$ and filter. Concentrated under reduced pressure on rota evaporator to give a residue which was purified by column chromatography by using $30 \%$ ethyl acetate in hexane, to obtained $3.24 \mathrm{~g}$ of product in $70 \%$ yield. Melting point is 174-176 ${ }^{\circ} \mathrm{C} .{ }^{1} \mathrm{H}$ NMR $\left(200 \mathrm{MHz}, \mathrm{CDCl}_{3}\right):{ }^{\delta} 3.65(\mathrm{~s}, 3 \mathrm{H}), 2.01-0.87(\mathrm{~m}, 2 \mathrm{H}), 0.64(\mathrm{~s}, 3 \mathrm{H})$. Mass: $(\mathrm{m} / \mathrm{z}): 362(\mathrm{M}+)$.

24-para-Toluene-sulfoxy-5 $\beta$-Cholane-3 $\alpha$-ol (3) Dissolved the $5 \beta$-cholane-3 $\alpha$-24-diol (2.5 g, $6.9 \mathrm{mmol})$ in THF $(15 \mathrm{ml})$ and cool to $0^{\circ} \mathrm{C}$. Added $1.8 \mathrm{~mL}(1.4 \mathrm{~g}, 13.8 \mathrm{mmol}, 2.0 \mathrm{eq})$ of triethylamine and followed by $2.63 \mathrm{~g}(13.8 \mathrm{mmol})$ of 4-Methyl-benzenesulfonyl chloride. Stirred and maintain at $4^{\circ} \mathrm{C}$ for $72 \mathrm{~h}$. Remove the solvent on rota evaporator. Extracted with ethyl acetate $(100 \mathrm{~mL} \times 2)$ and washed with $10 \% \mathrm{NaHCO}_{3}$ solution, brine solution, dried over $\mathrm{MgSO}_{4}$ and filter. Concentrated under reduced pressure on rota evaporator to give a residue which was purified by column chromatography by using $30 \%$ ethyl acetate in hexane, to obtained $1.0 \mathrm{~g}$ of product in $50 \%$ yield. ${ }^{1} \mathrm{H} \mathrm{NMR}\left(200 \mathrm{MHz}, \mathrm{CDCl}_{3}\right):{ }^{\delta} 7.73(\mathrm{~d}, 2 \mathrm{H}, J=8.0 \mathrm{~Hz}), 7.28(\mathrm{~d}, 2 \mathrm{H}, J=$ $8.0 \mathrm{~Hz}$ ), $3.93(\mathrm{t}, 2 \mathrm{H}, J=6.2 \mathrm{~Hz} \& 12.4 \mathrm{~Hz}), 3.55-3.42(\mathrm{~m}, 1 \mathrm{H}), 2.82(\mathrm{br}-\mathrm{s}, 1 \mathrm{H}, \mathrm{OH}), 2.37(\mathrm{~s}, 3 \mathrm{H})$, 2.00-0.81 ( $\mathrm{m}, 2 \mathrm{H}), 0.53(\mathrm{~s}, 3 \mathrm{H}) . \mathrm{NMR}\left(50 \mathrm{MHz}, \mathrm{CDCl}_{3}\right)$ : $\delta$ 144.4, 133.0, 129.6, 71.3, 71.0, $56.1,55.6,42.3,41.7,40.0,39.8,35.9,35.4,35.0,34.8,34.2,31.0,30.0,27.8,26.8,26.1,25.2$, 23.8, 23.0, 21.3, 20.4, 18.0, 11.6. Mass: $(\mathrm{m} / \mathrm{z}): 516(\mathrm{M}+)$. 


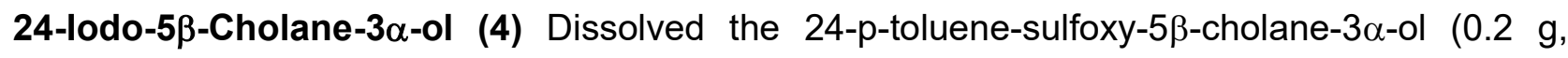
$0.383 \mathrm{mmol})$ in acetone $(10 \mathrm{~mL})$ and added $115 \mathrm{mg}(0.775 \mathrm{mmol})$ of sodium iodide. Heated at reflux for $4 \mathrm{~h}$. cool to room temperature and remove the solvent on rota evaporator. Extracted with ethyl acetate $(100 \mathrm{~mL} \times 2)$ and wash with $10 \% \mathrm{NaHCO}_{3}$ solution, brine solution, dried over $\mathrm{MgSO}_{4}$ and filter. Concentrated under reduced pressure on rota evaporator to give a residue which was purified by column chromatography by using $10 \%$ ethyl acetate in hexane, to obtained $165 \mathrm{mg}$ of the product in $90 \%$ yield. ${ }^{1} \mathrm{H}$ NMR $\left(200 \mathrm{MHz}, \mathrm{CDCl}_{3}\right):{ }^{\delta} 3.67-3.58(\mathrm{~m}, 1 \mathrm{H})$, 3.22-3.02 (m, 2H), 2.00-0.89 (m, 20H), $0.63(\mathrm{~s}, 3 \mathrm{H}) . \mathrm{NMR}\left(50 \mathrm{MHz}, \mathrm{CDCl}_{3}\right):{ }^{\delta} 71.5,56.3,55.8$, $42.5,41.9,40.2,39.9,36.6,36.1,35.6,35.2,34.8,34.3,30.2,30.1,28.1,27.0,26.2,24.0,23.2$, 20.6, 18.5, 11.8, 07.6. Mass: $(\mathrm{m} / \mathrm{z}): 472(\mathrm{M}+)$.

1-Methyl-[4,4']bipyridinium iodide (5) Dissolved 4,4-Bipyridine (5) $(2.5 \mathrm{~g}, 16.0 \mathrm{mmol})$ in dichloromethane and added $(1 \mathrm{~mL}, 2.25 \mathrm{~g}, 6.0 \mathrm{mmol})$ of methyl iodide. Stirred at room temperature for $12 \mathrm{~h}$. Yellow precipitate is formed. Filter to obtained solid, the filtrate mainly contains unreacted starting material. The solid product on recrystallization in ethanol at hot condition, give yellow solid in 90\% yield. ${ }^{1} \mathrm{H}$ NMR $(200 \mathrm{MHz}$, DMSO-d 6$)$ : ${ }^{\delta} 9.14(\mathrm{~d}, 2 \mathrm{H}, \mathrm{J}=6.6$ $\mathrm{Hz}), 8.86(\mathrm{~d}, 2 \mathrm{H}, J=6 \mathrm{~Hz}), 8.62(\mathrm{~d}, 2 \mathrm{H}, J=6.2 \mathrm{~Hz}), 8.04(\mathrm{~d}, 2 \mathrm{H}, J=6.2 \mathrm{~Hz}), 4.38(\mathrm{~s}, 3 \mathrm{H}) .{ }^{13} \mathrm{C}-$ NMR (50 MHz, DMSO-d6): ${ }^{\delta} 151.9,151.2,146.3,140.9,125.1,122.0,47.8$. Mass: $(\mathrm{m} / \mathrm{z}): 171$ $(\mathrm{M}+)$.

$4 \alpha, 6 \alpha$-Dimethyl-7-[1-methyl-4-(1'-methyl-[4,4'] bipyridinyl-1-yl)-butyl]-octadecahydro-

chrysen-2-ol (6) Taken (0. $2 \mathrm{~g}, 0.673 \mathrm{mmol}$ ) of 1-Methyl-[4,4']bipyridinium iodide (5) and 24iodo-5- $\beta$-cholane-3- $\alpha$-ol (4) (350 $\mathrm{mg}, 0.74 \mathrm{mmol})$ in acetonitrile $(10 \mathrm{~mL})$ and heated at reflux for Page 8 of 15 
$48 \mathrm{~h}$. Pout into water, extracted with ethyl acetate to remove iodo compound and filter the aqueous layer to get $490 \mathrm{mg}$ of solid in 95\% yield. ${ }^{1} \mathrm{H}$ NMR (200 MHz, DMSO-d6): $\delta 9.41$ (d, $2 \mathrm{H}, J=5.4 \mathrm{~Hz}), 9.26(\mathrm{~d}, 2 \mathrm{H}, J=5.4 \mathrm{~Hz}), 8.78(\mathrm{t}, 4 \mathrm{H}, J=4.6 \& 7.8 \mathrm{~Hz}), 4.68-4.58(\mathrm{~m}, 1 \mathrm{H}),, 4.42-$ $4.32(\mathrm{~m}, 2 \mathrm{H}), 2.46(\mathrm{~s}, 3 \mathrm{H}), 2.00-0.81(\mathrm{~m}, 20 \mathrm{H}), 0.63(\mathrm{~s}, 3 \mathrm{H})$. Mass: $(\mathrm{m} / \mathrm{z}): 768(\mathrm{M}+)$ (with iodo), 516 (without iodo). FAB: 516.

4-,4'-Dimethyl,2,2'-bipyridine (7): Charged $28 \mathrm{~g}$ of $\mathrm{Pd} / \mathrm{C}$ into two neck-two-liter round bottom flask equipped with reflux condenser and pour $700 \mathrm{~mL}(665 \mathrm{~g})$ of 4-picoline. Heated at reflux $\left(250^{\circ} \mathrm{C}\right)$ for 4 days and cool to $150^{\circ} \mathrm{C}$. Add $250 \mathrm{~mL}$ of benzene and heat at reflux $\left(250^{\circ} \mathrm{C}\right)$ for 1 h. Cool to $150^{\circ} \mathrm{C}$. Then filter through celite pad. The filtrate was distilled under vacuum on rota evaporator to get the residue $(20 \mathrm{~g})$. Dissolved the residue in $200 \mathrm{~mL}$ of acetone and added water $(500 \mathrm{~mL})$ to get precipitate. Filtered the precipitate and dry in vacuum to get $15 \mathrm{~g}$ of product in $1.15 \%$ yield. ${ }^{1} \mathrm{H}$ NMR (200 MHz, DMSO-d 6$): \quad \delta 8.49(\mathrm{~d}, 2 \mathrm{H}, J=4.8 \mathrm{~Hz}), 8.20(\mathrm{~s}, 2 \mathrm{H})$, $7.24(\mathrm{~d}, 2 \mathrm{H}, \mathrm{J}=4.8 \mathrm{~Hz}), 2.39(\mathrm{~s}, 6 \mathrm{H})$.

4'-Methyl-[2,2']bipyridinyl-4-carbaldehyde (8) Dissolved the $2.6 \mathrm{~g}$ (14 mmol) of 4,4'Dimethyl,2,2'-bipyridine (7) in 1,4-dioxane $(50 \mathrm{~mL})$ and added $1.72 \mathrm{~g}(15.5 \mathrm{~mol})$ of selenium dioxide. Heated at reflux for $24 \mathrm{~h}$. Cool to $90^{\circ} \mathrm{C}$ and filter the selenium dioxide to get the filterate-1. Cool the filterate- 1 to room temperature and filtered to remove selenium dioxide and to get the fitlerate-2. The filterate-2 on concentration gives the residue. Dissolve the residue in ethyl acetate $(250 \mathrm{~mL})$ and filtered to get filterate-3. The filterate-3 was extracted with $1.0 \mathrm{M}$ sodium carbonate (100 $\mathrm{mL} \times 2)$ to remove the acid (side product), then washed with $0.3 \mathrm{M}$ $\mathrm{Na}_{2} \mathrm{~S}_{2} \mathrm{O}_{5}(100 \mathrm{~mL} \times 3)$. The aqueous layer was neutralized to $\mathrm{pH}=10$ by addition of solid, Page 9 of 15 
sodium carbonate. Extracted with DCM (100 mL X 2) and wash with $10 \% \mathrm{NaHCO}_{3}$ solution, brine solution, dried over $\mathrm{MgSO}_{4}$ and filtered. Concentrated under reduced pressure on rota evaporator to give $1.4 \mathrm{~g}$ of pure aldehyde in $50 \%$ yield. ${ }^{1} \mathrm{H}$ NMR (200 MHz, DMSO-d6): ${ }^{\delta} 10.20$ (s, 1H), $8.91(\mathrm{~d}, 1 \mathrm{H}, J=5.0 \mathrm{~Hz}), 8.85(\mathrm{~s}, 1 \mathrm{H}), 8.59(\mathrm{~d}, 1 \mathrm{H}, J=5.0 \mathrm{~Hz}), 8.29(\mathrm{~s}, 1 \mathrm{H}), 7.74(\mathrm{~d}, 1 \mathrm{H}$, $J=5.0 \mathrm{~Hz}$ ), $7.22(\mathrm{~d}, 1 \mathrm{H}, J=5.0 \mathrm{~Hz}$ ), 2.47 (s, 3H). IR (nujol): 1736, 1690, 1665, 1630, 1595, 1556.

4'-Methyl-[2,2']bipyridinyl-4-carboxylic acid (9) Dissolved $1.4 \mathrm{~g}$ (7.0 mmol) of 4'- Methyl[2,2']bipyridinyl-4-carbaldehyde (8) in ethanol $(50 \mathrm{~mL})$ and protect with aluminum foil. Added freshly prepared silver nitrate solution $(1.4 \mathrm{~g}, 8.4 \mathrm{~mol})$ in $10 \mathrm{ml}$ of water). Added $570 \mathrm{mg}(0.014$ mol) of $\mathrm{NaOH}$ solution (in $10 \mathrm{~mL}$ of water) drop-wise over a period of 30 minutes. Stirred the reaction mixture in under dark place for $15 \mathrm{~h}$, removed the ethanol and water from reaction mixture on rota evaporator to get residue. Dissolved the residue in $1.0 \mathrm{M} \mathrm{NaOH}$ solution (100 $\mathrm{mL}$ ) and filtered to remove the silver oxide and metallic silver. Extracted with dichloromethane to remove unreacted aldehyde from aqueous layer. The aqueous layer on neutralized with 1:1 solution of $4 \mathrm{~N}$ hydrochloric acid and acetic acid to get white gelatineous ppt. Stored in cool condition for overnight. Filtered the precipitate and dry under vacuum to get $840 \mathrm{mg}$ of product in $55 \%$ yield. ${ }^{1} \mathrm{H}$ NMR $\left(200 \mathrm{MHz}, \mathrm{D}_{2} \mathrm{O}\right):{ }^{\delta} 8.40(\mathrm{~d}, 1 \mathrm{H}, J=5.0 \mathrm{~Hz}), 8.16(\mathrm{~d}, 1 \mathrm{H}, J=5.0 \mathrm{~Hz})$, $7.92(\mathrm{~s}, 1 \mathrm{H}), 7.55(\mathrm{~d}, 1 \mathrm{H}, J=5.2 \mathrm{~Hz}), 7.43(\mathrm{~s}, 1 \mathrm{H}), 7.04(\mathrm{~d}, 1 \mathrm{H}, J=4.8 \mathrm{~Hz}) 2.14(\mathrm{~s}, 3 \mathrm{H})$. Mass: (m/z): $215(\mathrm{M}+)$. IR (nujol): 1721, 1698, 1681, 1650, 1601, 1561.

COMPLEX-1 (10): Taken 70 mg (0.31 mmol) of 4'-Methyl-[2,2']bipyridinyl-4-carboxylic acid (9), HOBT (45 mg, $0.31 \mathrm{mmol})$, DCC (70 mg, $0.31 \mathrm{mmol})$ in DMF (5 mL) and stir under nitrogen 
atmosphere for $6 \mathrm{~h}$. Add $0.2 \mathrm{~g}(0.260 \mathrm{mmol})$ compound 6 and stir at room temperature for $24 \mathrm{~h}$.

During this time, precipitate is formed, and solution is turned to red in color. Removed the DMF solvent on rota evaporator to get residue and quenched the residue with water. Extracted with ethyl acetate to remove excess of reagents. Filtered the aqueous layer to remove urea side product formed and unreacted acid compound. To aqueous layer (contains essentially pure product) add ammonium hexafluoro phosphate to get precipitate, concentrated the aqueous layer to half of its volume and cool in freezer to and filtered to get $250 \mathrm{mg}$ of solid product in 95\% yield. ${ }^{1} \mathrm{H}$ NMR (200 MHz, DMSO-d $): \quad \delta$ 9.38-9.28 (d, 2H, J = 20.0 Hz), 8.76-8.61 (m, 2H), $8.29(\mathrm{~s}, 2 \mathrm{H}), 7.91(\mathrm{~s}, 2 \mathrm{H}), 7.67(\mathrm{~s}, 2 \mathrm{H}), 7.37(\mathrm{~s}, 2 \mathrm{H}), 7.12(\mathrm{~s}, 2 \mathrm{H}), 4.68-4.58(\mathrm{~m}, 3 \mathrm{H}), 2.46$ (s, $6 \mathrm{H}), 2.00-0.81(\mathrm{~m}, 20 \mathrm{H}), 0.63(\mathrm{~s}, 3 \mathrm{H})$. Mass m/z: 1000, $712(\mathrm{M}+), 647,516(100 \%)$, 495, 363, 251. IR (nujol): 1724, 1647, 1509, 1377, 1182, 834. $\mathrm{C}_{47} \mathrm{H}_{60} \mathrm{~N}_{4} 0_{2}(\mathrm{PF} 6)_{2}=1000$. Solubility studies: (a) Complex-1 soluble in water, DMF. Insoluble in ethyl acetate. (b) Acid soluble in DMF, insoluble in ethyl acetate, water. (c) DCC and HOBT soluble in ethyl acetate, DMF, and insoluble in water.

Ruthenium, bis(2,2'-bipyridine-kN1,kN1')dichloro (11): To a solution of $2.5 \mathrm{~g}$ (9.5 mmol,1.0 eq) of $\mathrm{RuCl}_{3} .3 \mathrm{H}_{2} \mathrm{O}$ and $2.75 \mathrm{~g}(61 \mathrm{mmol}, 6.4 \mathrm{eq})$ of $\mathrm{LiCl}$ in $25 \mathrm{ml}$ DMF was added $2.94 \mathrm{~g}$ (19 mmol, 2.0 eq) bipyridine at room temperature. Heated at reflux for 45 minutes, while continuously check the tlc for emission under uv lamp. Cool to RT. Poured into $100 \mathrm{~mL}$ of acetone. After cooling in freezer for $24 \mathrm{~h}$, ppt is formed. Filtered and washed with water and acetone until pale color appeared. After $2 \mathrm{~h}$ dry in vacuum, obtained $1.9 \mathrm{~g}$ of product in $40 \%$ yield. Melting Point $=196-198^{\circ} \mathrm{C}$. Mass $(\mathrm{m} / \mathrm{z}): 484(\mathrm{M}+)$. 
Ruthenium, bis(2,2'-bipyridine-kN1,kN1')[carbonato(2-)-kO,kO']-, (OC-6-22) (12): charged $2.0 \mathrm{~g}(4.13 \mathrm{mmol})$ of compound $11 \mathrm{in} 50 \mathrm{ml}$ of water, heated at reflux under argon atmosphere for 15 minutes. Added $6.6 \mathrm{~g}(6.3 \mathrm{mmol})$ of sodium carbonate and heated at reflux for 45 minutes. Cool to RT and filtered, washed the solid with water and dry in vacuum for $2 \mathrm{~h}$ to obtained $1.3 \mathrm{~g}$ of product 12 in 67 yield. Mass: $474(\mathrm{M}+)$.

FINAL COMPLEX (13): Take Compound $10,(0.1 \mathrm{~g}, 0.1 \mathrm{mmol})$ and $52 \mathrm{mg}(0.11 \mathrm{mg}, 0.11$ mmol) of ruthenium carbonate complex (12) in DMF $(5 \mathrm{~mL})$ and heat at $100^{\circ} \mathrm{C}$ for $6 \mathrm{~h}$. Monitored by uv light. Clear solution is formed. Removed the solvent on rota evaporator to get residue. Dissolved the residue in water (clear solution is formed) and add ammonium hexafluoro phosphate to get precipitate. Filtered the precipitate and dry under vacuum to get $120 \mathrm{mg}$ of the product. ${ }^{1} \mathrm{H}$ NMR $(200 \mathrm{MHz}$, DMSO-d $)$ : ${ }^{\delta} 9.36(\mathrm{~m}, 1 \mathrm{H}), 9.26(\mathrm{~m}, 2 \mathrm{H}), 8.91(\mathrm{~m}$, 5H), $8.16(\mathrm{~m}, 6 \mathrm{H}), 7.88(\mathrm{~m}, 6 \mathrm{H}), 7.78(\mathrm{~s}, 2 \mathrm{H}), 7.55(\mathrm{~s}, 2 \mathrm{H}), 7.34(\mathrm{~s}, 2 \mathrm{H}), 7.09(\mathrm{~s}, 2 \mathrm{H}), 6.96(\mathrm{~s}$, 2H), 4.68-4.58 (m, 3H,), $2.46(\mathrm{~s}, 6 \mathrm{H}), 2.00-0.81(\mathrm{~m}, 20 \mathrm{H}), 0.63(\mathrm{~s}, 3 \mathrm{H}) . \mathrm{IR}$ (nujol): 1734, 1685, 1647, 1508, 1376, 838, 720. Mass: $(\mathrm{m} / \mathrm{z}):$ 1693, 1533, 1329, 1191, $1153(\mathrm{M}+), 1006,860,661$, 561, 215, 145,117. FAB: 1190, 1173, 1056, 1005, 661, 154, 136. Solubility studies: Compound (10): soluble in DMF, DMSO, insoluble in methanol, ethanol, and sparingly soluble in acetonitrile. Ruthenium carbonate (12): water soluble, DMF sparingly soluble. Product (13): soluble in acetonitrile and DMSO. Insoluble in methanol, ethanol.

\section{- Acknowledgement:}

G.S.R thankful to National Science Council of Taiwan, (ROC) for financial support in the form of 
Post-Doctoral Fellowship during February 2000-July 2003. G.S.R is thankful to Chang I Jy at

National Taiwan Normal University, Taipei, Taiwan, for conducting the experiments and collection and processing of the spectral data and X-ray data are gratefully acknowledged.

\section{- Competing interests:}

There is no Competing Interests pending

\section{Reference:}

1 Chenneberg, L. et al. Visible Light Photocatalytic Reduction of O-Thiocarbamates: Development of a Tin-Free Barton-McCombie Deoxygenation Reaction. Advanced Synthesis \& Catalysis 356, 2756-2762, doi:https://doi.org/10.1002/adsc.201400729 (2014).

2 Dauncey, E. M., Morcillo, S. P., Douglas, J. J., Sheikh, N. S. \& Leonori, D. Photoinduced Remote Functionalisations by Iminyl Radical Promoted $\mathrm{C}-\mathrm{C}$ and $\mathrm{C}-\mathrm{H}$ Bond Cleavage Cascades. $\begin{array}{lllll}\text { Angewandte Chemie } \quad \text { International } & \text { Edition }\end{array}$ doi:https://doi.org/10.1002/anie.201710790 (2018).

3 Liang, Y., Zhang, X. \& MacMillan, D. W. C. Decarboxylative sp3 C-N coupling via dual copper and photoredox catalysis. Nature (London, U. K.) 559, 83-88, doi:10.1038/s41586-018-0234-8 (2018).

4 Zhang, J., Meng, Z., Liu, J., Chen, S. \& Yu, Z. Spherical colloidal photonic crystals with selected lattice plane exposure and enhanced color saturation for dynamic optical displays. ACS Appl. Mater. Interfaces 11, 42629-42634, doi:10.1021/acsami.9b15352 (2019).

5 Ruess, R. et al. Diverging surface reactions at TiO2- or ZnO-based photoanodes in dye-sensitized solar cells. Physical Chemistry Chemical Physics 21, 13047-13057, doi:10.1039/C9CP01215J (2019).

6 Shaw, M. H., Twilton, J. \& MacMillan, D. W. C. Photoredox Catalysis in Organic Chemistry. The Journal of Organic Chemistry 81, 6898-6926, doi:10.1021/acs.joc.6b01449 (2016).

7 McAtee, R. C., McClain, E. J. \& Stephenson, C. R. J. Illuminating Photoredox Catalysis. Trends in Chemistry 1, 111-125, doi:10.1016/j.trechm.2019.01.008 (2019).

8 Cruz, A. J., Kirgan, R., Siam, K., Heiland, P. \& Rillema, D. P. Photochemical and photophysical properties of ruthenium(II) bis-bipyridine bis-nitrile complexes: Photolability. Inorg. Chim. Acta 363, 2496-2505, doi:10.1016/j.ica.2010.04.014 (2010).

9 Su, C.-H., Chen, H.-Y., Tsai, K. Y.-D. \& Chang, I. J. Photophysical Properties of Ruthenium Bipyridine (4-Carboxylic acid-4'-methyl-2,2'-bipyridine) Complexes and Their Acid-Base Chemistry. The Journal of Physical Chemistry B 111, 6857-6860, doi:10.1021/jp070847i (2007).

10 Karidi, K. et al. Synthesis, Characterization, and DNA-Binding Studies of Nitro(oligopyridine)ruthenium(II) Complexes. Inorganic Chemistry 45, 10282-10292, 
doi:10.1021/ic0608039 (2006).

11 de Carvalho, I. M. M., Diógenes, I. C. N., Moreira, Í. d. S. \& Gehlen, M. H. Effect of the pH in the luminescence of ruthenium tris-bipyridine derivatives. Journal of Photochemistry and Photobiology A: Chemistry 171, 107-112, doi:https://doi.org/10.1016/j.jphotochem.2004.09.010 (2005).

12 Chin, T. et al. Molecular Recognition and Reactivity of Ruthenium(II) Bipyridine Barbituric Acid Guests in the Presence of Complementary Hosts: Ruthenium(II) Promoted Enolization of Barbituric Acids in Guest-Host Complexes. Journal of the American Chemical Society 119, 12849-12858, doi:10.1021/ja971481y (1997).

13 Kirby, J. P., Roberts, J. A. \& Nocera, D. G. Significant Effect of Salt Bridges on Electron Transfer. Journal of the American Chemical Society 119, 9230-9236, doi:10.1021/ja970176+ (1997).

14 Fan, B. et al. Synthesis and Physical Characterization of Novel Heme-Based Model Systems for Photoinitiated Electron Transfer. 1. Complexation of a RuProHis Bifunctional Peptide and Microperoxidase-11. Inorganic Chemistry 36, 3839-3846, doi:10.1021/ic9700415 (1997).

15 Okura, I., Kaji, N., Aono, S. \& Nishisaka, T. Photoredox properties of viologen linked porphyrins. Bull. Chem. Soc. Jpn. 60, 1243-1247, doi:10.1246/bcsj.60.1243 (1987).

16 Duan, F., Liu, G., Fan, C. \& Pu, S. Synthesis and photochromism of a novel amphiphilic diarylethene bearing two cholic acid groups. Tetrahedron Lett. 57, 1963-1966, doi:10.1016/j.tetlet.2016.03.079 (2016).

17 Striepe, L. \& Baumgartner, T. Viologens and Their Application as Functional Materials. Chemistry - A European Journal 23, 16924-16940, doi:https://doi.org/10.1002/chem.201703348 (2017).

18 Pan, L. P., Hibdon, S., Liu, R. Q., Durham, B. \& Millett, F. Intracomplex electron transfer between ruthenium-cytochrome c derivatives and cytochrome c oxidase. Biochemistry 32, 84928498, doi:10.1021/bi00084a014 (1993).

19 Pascaly, M., Yoo, J. \& Barton, J. K. DNA Mediated Charge Transport: Characterization of a DNA Radical Localized at an Artificial Nucleic Acid Base. Journal of the American Chemical Society 124, 9083-9092, doi:10.1021/ja0202210 (2002).

20 Chang, I. J., Gray, H. B. \& Winkler, J. R. High-driving-force electron transfer in metalloproteins: intramolecular oxidation of ferrocytochrome $\mathrm{c}$ by $\mathrm{Ru}\left(2,2^{\prime}\right.$-bpy)2(im)(his-33)3+. Journal of the American Chemical Society 113, 7056-7057, doi:10.1021/ja00018a064 (1991).

21 Sun, L. et al. Hydrogen-Bond Promoted Intramolecular Electron Transfer to Photogenerated Ru(III): A Functional Mimic of TyrosineZ and Histidine 190 in Photosystem II. Journal of the American Chemical Society 121, 6834-6842, doi:10.1021/ja984048c (1999).

22 Reddy, G. S., Chen, H.-Y. \& Chang, I. J. Cysteine-Specific Blue Fluorescence Probe. Journal of the Chinese Chemical Society 53, 1303-1308, doi:10.1002/jccs.200600174 (2006).

23 Reddy Gondi, S. \& Son, D. Y. Cholane Derivatives with Potential Ligating Groups at the 3- and 24-Positions. Synthetic Communications 36, 1317-1331, doi:10.1080/00397910500521803 (2006).

24 Xiao, Y., Chu, L., Sanakis, Y. \& Liu, P. Revisiting the IspH Catalytic System in the Deoxyxylulose Phosphate Pathway: Achieving High Activity. J. Am. Chem. Soc. 131, 9931-9933, 
doi:10.1021/ja903778d (2009).

25 MacInnes, M. M. et al. Discovery of unusually stable reduced viologen via synergistic folding and encapsulation. J. Electrochem. Soc. 166, H825-H834, doi:10.1149/2.0711915jes (2019).

26 Jørgensen, C. T., Pedersen, C. \& Søtofte, I. A New Method for the Synthesis of 2,3-Aziridino-2,3dideoxyhexonamides and Their Conversion into 3-Amoni-2,3-dideoxyhexonic Acids. Synthesis 1998, 325-328 (1998).

27 Peek, B. M. et al. Synthesis of redox derivatives of lysine and related peptides containing phenothiazine or tris(2,2`-bipyridine)ruthenium(II). International Journal of Peptide and Protein Research 38, 114-123, doi:10.1111/j.1399-3011.1991.tb01418.x (1991).

28 Meylemans, H. A., Lei, C.-F. \& Damrauer, N. H. Ligand Structure, Conformational Dynamics, and Excited-State Electron Delocalization for Control of Photoinduced Electron Transfer Rates in Synthetic Donor-Bridge-Acceptor Systems. Inorg. Chem. 47, 4060-4076, doi:10.1021/ic701776k (2008).

29 Seok, W. K. \& Meyer, T. J. Multiple electron oxidation of phenols by an oxo complex of ruthenium(IV). J. Am. Chem. Soc. 110, 7358-7367, doi:10.1021/ja00230a016 (1988).

30 Adamson, K., Dolan, C., Moran, N., Forster, R. J. \& Keyes, T. E. RGD Labeled Ru(II) Polypyridyl Conjugates for Platelet Integrin $\alpha \operatorname{Ilb} \beta 3$ Recognition and as Reporters of Integrin Conformation. Bioconjugate Chemistry 25, 928-944, doi:10.1021/bc5000737 (2014).

31 Nagai, T. Racemization of phenylalanine coordinated to bis(2,2'-bipyridine)ruthenium(II) complexes in basic aqueous solutions. Bull. Chem. Soc. Jpn. 62, 2897-2901, doi:10.1246/bcsj.62.2897 (1989).

32 Sun, S. et al. Synthesis and DNA photocleavage study of Ru(bpy)32+-(CH2)n-MV2+ complexes. Dalton Trans. 39, 4411-4416, doi:10.1039/b927568a (2010). 